Prepared in cooperation with the Federal Emergency Management Agency

\title{
High-Water Marks from Tropical Storm Irene for Selected River Reaches in Northwestern Massachusetts, August 2011
}

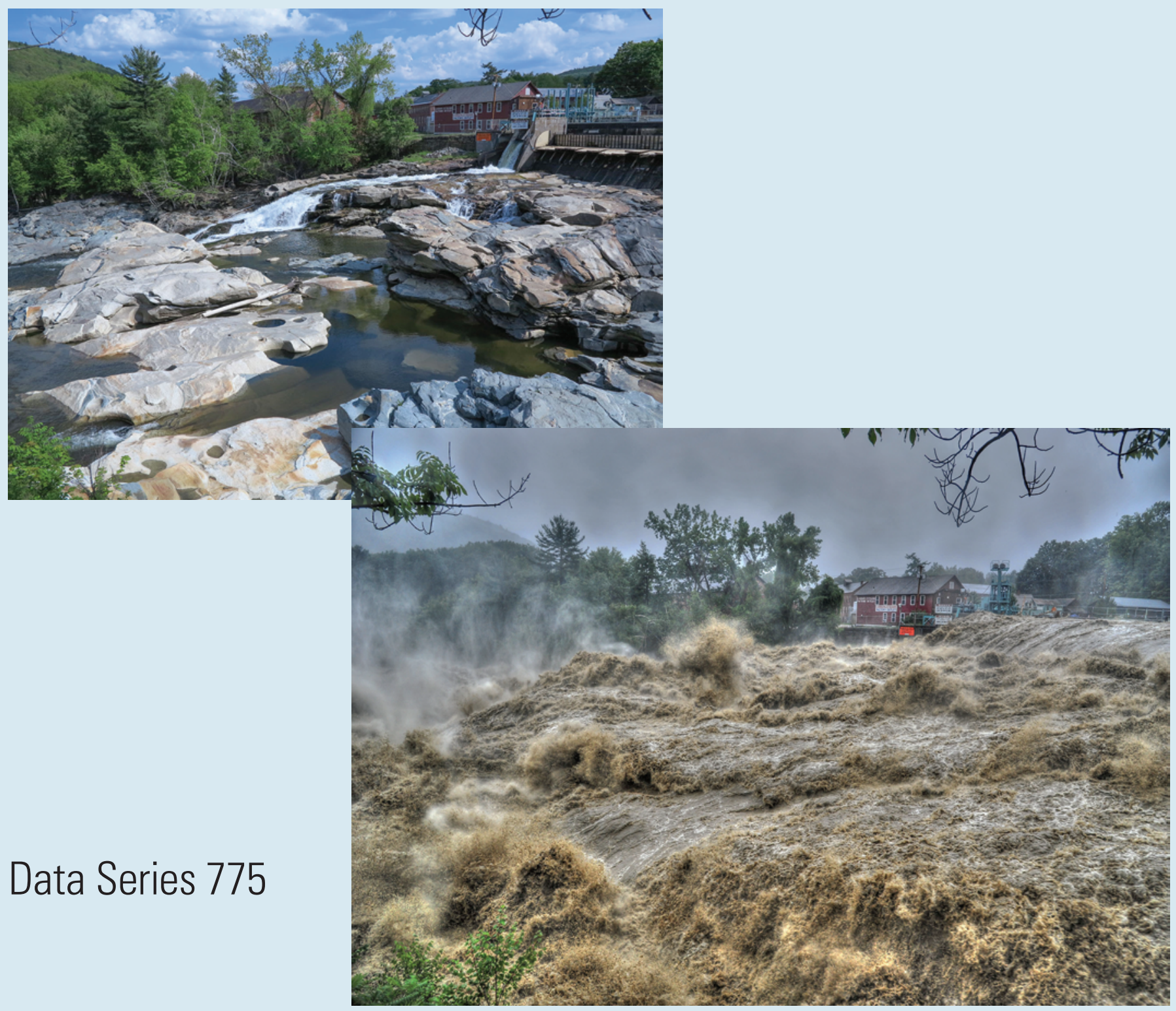

U.S. Department of the Interior

U.S. Geological Survey 
Front cover. Photographs of Deerfield River at dam \#3 at Shelburne Falls, Massachusetts. Top left photograph was taken on May 14, 2012, during near-normal flows. The rocky area below the dam is called the Glacial Potholes. The bottom right photograph was taken on August 28, 2011, during flood flows from tropical storm Irene. Photographs by John E. Robison, Amherst, Massachusetts.

Back cover. Photograph of Deerfield River at the Bridge Street bridge (left) and the Bridge of Flowers (right) at Shelburne Falls, Massachusetts, taken on August 28, 2011, during flood flows from tropical storm Irene. Photograph by John E. Robison, Amherst, Massachusetts. 


\section{High-Water Marks from Tropical Storm Irene for Selected River Reaches in Northwestern Massachusetts, August 2011}

By Gardner C. Bent, Laura Medalie, and Martha G. Nielsen

Prepared in cooperation with the Federal Emergency Management Agency

Data Series 775 


\title{
U.S. Department of the Interior SALLY JEWELL, Secretary
}

\section{U.S. Geological Survey Suzette M. Kimball, Acting Director}

\author{
U.S. Geological Survey, Reston, Virginia: 2013
}

For more information on the USGS - the Federal source for science about the Earth, its natural and living resources, natural hazards, and the environment, visit http://www.usgs.gov or call 1-888-ASK-USGS.

For an overview of USGS information products, including maps, imagery, and publications, visit http://www.usgs.gov/pubprod

To order this and other USGS information products, visit http://store.usgs.gov

Any use of trade, firm, or product names is for descriptive purposes only and does not imply endorsement by the U.S. Government.

Although this information product, for the most part, is in the public domain, it also may contain copyrighted materials as noted in the text. Permission to reproduce copyrighted items must be secured from the copyright owner.

Suggested citation:

Bent, G.C., Medalie, Laura, and Nielsen, M.G., 2013, High-water marks from tropical storm Irene for selected river reaches in northwestern Massachusetts, August 2011: U.S. Geological Survey Data Series 775, 13 p., http://pubs.usgs.gov/ds/775/. 


\section{Contents}

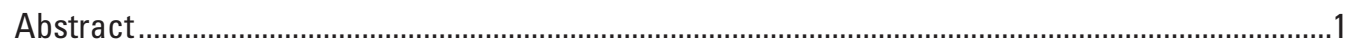

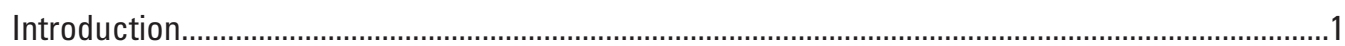

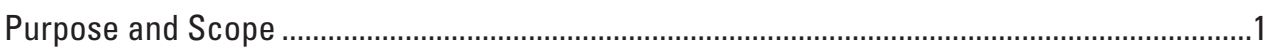

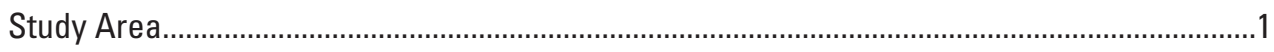

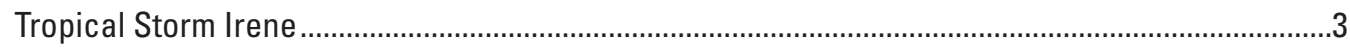

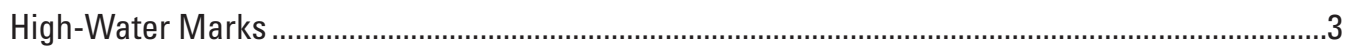

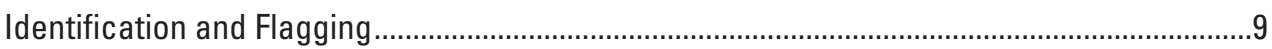

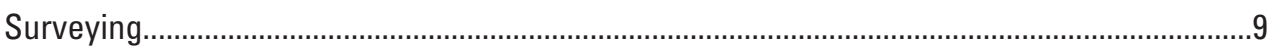

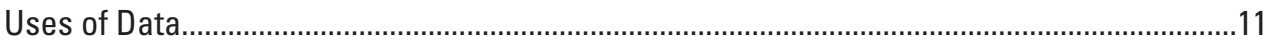

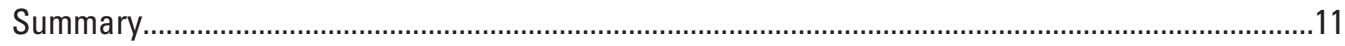

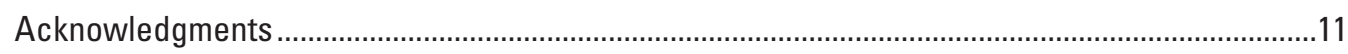

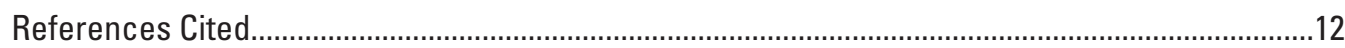

Appendix 1. Elevations of High-Water Marks Surveyed in the Deerfield and Hudson-Hoosic

River Basins in Northwestern Massachusetts Resulting from Flooding from Tropical

Storm Irene, August 28-29, 2011...............................................................................13

Appendix 2. GoogleEarth Map of High-Water Marks in the Deerfield and Hudson-Hoosic

River Basins in Northwestern Massachusetts Resulting from Flooding from Tropical

Storm Irene, August 28-29, 2011.

\section{Figures}

1. Map showing locations of U.S. Geological Survey streamgages with at least 25 years of record in western Massachusetts

2. Map showing distribution of rainfall and path of tropical storm Irene across western Massachusetts on August 28-29, 2011.

3. Hydrographs for U.S. Geological Survey streamgages $A$, Hoosic River near Williamstown (station 01332500) and B, Deerfield River near West Deerfield (station 01170000) in Massachusetts, showing a rapid rise in gage height due to tropical storm Irene, August 28-29, 2011

4. Photographs showing examples of high-water marks associated with flooding from tropical storm Irene in the Deerfield and Hudson-Hoosic River Basins in northwestern Massachusetts, August 28-29, 2011: A, B, mud and debris line on buildings; $C$, debris on the ground; $D$, wash line on the ground; and $E$, debris on tree...

5. Map showing locations of surveyed high-water marks from flooding due to tropical storm Irene in the Deerfield and Hudson-Hoosic River Basins in northwestern Massachusetts, August 28-29, 2011. 


\section{Tables}

1. Peak streamflows and gage heights compared to historical peaks for U.S.

Geological Survey streamgages in western Massachusetts, August 28-29, 2011 ...........5

2. Quantitative scale to rate accuracy of high-water marks..................................................

3. Quality assurance of survey equipment used by the U.S. Geological Survey to determine positions of high-water marks from tropical storm Irene relative to National Geodetic Survey benchmarks in and near the Deerfield and HudsonHoosic River Basins, western Massachusetts, June through August 2012.

\section{Conversion Factors, Datum, and Abbreviations}

Inch/Pound to SI

\begin{tabular}{lll}
\hline \multicolumn{1}{c}{ Multiply } & By & \multicolumn{1}{c}{ To obtain } \\
\hline & Length & \\
\hline inch (in.) & 2.54 & centimeter $(\mathrm{cm})$ \\
foot $(\mathrm{ft})$ & 0.3048 & meter $(\mathrm{m})$ \\
mile $(\mathrm{mi})$ & 1.609 & kilometer $(\mathrm{km})$ \\
\hline & Area & \\
\hline square mile $\left(\mathrm{mi}^{2}\right)$ & 2.590 & square kilometer $\left(\mathrm{km}^{2}\right)$ \\
\hline & Flow rate & \\
\hline cubic foot per second $\left(\mathrm{ft}^{3} / \mathrm{s}\right)$ & 0.02832 & cubic meter per second $\left(\mathrm{m}^{3} / \mathrm{s}\right)$ \\
\hline
\end{tabular}

Vertical coordinate information is referenced to the North American Vertical Datum of 1988 (NAVD 88).

Horizontal coordinate information is referenced to the North American Datum of 1983 (NAD 83).

Elevation, as used in this report, refers to distance above the vertical datum.

\section{Abbreviations}

FEMA Federal Emergency Management Agency

GPS Global Positioning System

HWM High-water mark

NGS National Geodetic Survey

USGS U.S. Geological Survey 


\title{
High-Water Marks from Tropical Storm Irene for Selected River Reaches in Northwestern Massachusetts, August 2011
}

\author{
By Gardner C. Bent, Laura Medalie, and Martha G. Nielsen
}

\section{Abstract}

A Presidential Disaster Declaration was issued for Massachusetts, with a focus on the northwestern counties, following flooding from tropical storm Irene on August 2829,2011 . Three to 10 inches of rain fell during the storm on soils that were susceptible to flash flooding because of wet antecedent conditions. The gage height at one U.S. Geological Survey (USGS) streamgage rose nearly 20 feet in less than 4 hours because of the combination of saturated soils and intense rainfall. Eight of 16 USGS long-term streamgages in western Massachusetts set new peaks of record on August 28 or $29,2011$.

To document the historic water levels of the streamflows from tropical storm Irene, the USGS identified, flagged, and surveyed 323 high-water marks in the Deerfield and HudsonHoosic River basins in northwestern Massachusetts. Areas targeted for high-water marks were generally upstream and downstream from structures along selected river reaches. Elevations from high-water marks can be used to confirm peak river stages or help compute peak streamflows, to calibrate hydraulic models, or to update flood-inundation and recovery maps. For areas in western Massachusetts that flooded as a result of tropical storm Irene, high-water marks surveyed for this study have helped to confirm or determine instantaneous peak river gage heights at several USGS streamgages.

\section{Introduction}

The 3 to 10 inches of rainfall from tropical storm Irene resulted in historic rainfall and flooding on August 28-29, 2011, in western Massachusetts. On the basis of preliminary damage assessments, President Obama declared a major disaster in the Commonwealth of Massachusetts on September 3, 2011, with individual and public assistance available for Berkshire and Franklin Counties (Federal Emergency Management Agency, 2013). On October 20, 2011, the Presidential Disaster Declaration (FEMA-4028-DR) also designated Hampden and Hampshire Counties in western Massachusetts (plus five other counties in eastern Massachusetts) as eligible for public assistance (Federal Emergency Management Agency, 2013). As of February 2013, Federal financial assistance to Massachusetts for recovery from tropical storm Irene allotted more than $\$ 11$ million for individual assistance and more than $\$ 53$ million for public assistance (Federal Emergency Management Agency, 2013).

In response to the Presidential Disaster Declaration for Massachusetts resulting from tropical storm Irene (DR-4028), a Federal Emergency Management Agency (FEMA) Mission Assignment was authorized for the U.S. Geological Survey (USGS) to identify and flag high-water marks (HWMs) in northwestern Massachusetts, specifically along river reaches in the Deerfield and Hudson-Hoosic River Basins and to survey their elevations. An April 2012 Interagency Agreement between FEMA Region I (New England) and USGS authorized the surveying of HWM elevations to the North American Vertical Datum of 1988 (NAVD 88) for selected river reaches in northwestern Massachusetts as a result of tropical storm Irene.

\section{Purpose and Scope}

The purpose of this report is to document and provide data on HWMs from tropical storm Irene on August 28-29, 2011, for selected river reaches in the Deerfield and HudsonHoosic River Basins in northwestern Massachusetts. Methods used to identify, flag, and survey HWMs to vertical and horizontal datums are described. This report also presents a summary of gage heights and peak streamflows, in some instances verified by HWMs, resulting from tropical storm Irene at USGS streamgages throughout western Massachusetts.

\section{Study Area}

HWMs were identified in the Deerfield and HudsonHoosic River Basins in northwestern Massachusetts (fig. 1). Elevations in northwestern Massachusetts range from Mount Greylock at 3,487 feet (ft) to the mouth of the Deerfield River at about $120 \mathrm{ft}$ above sea level (NGVD 88). Western 


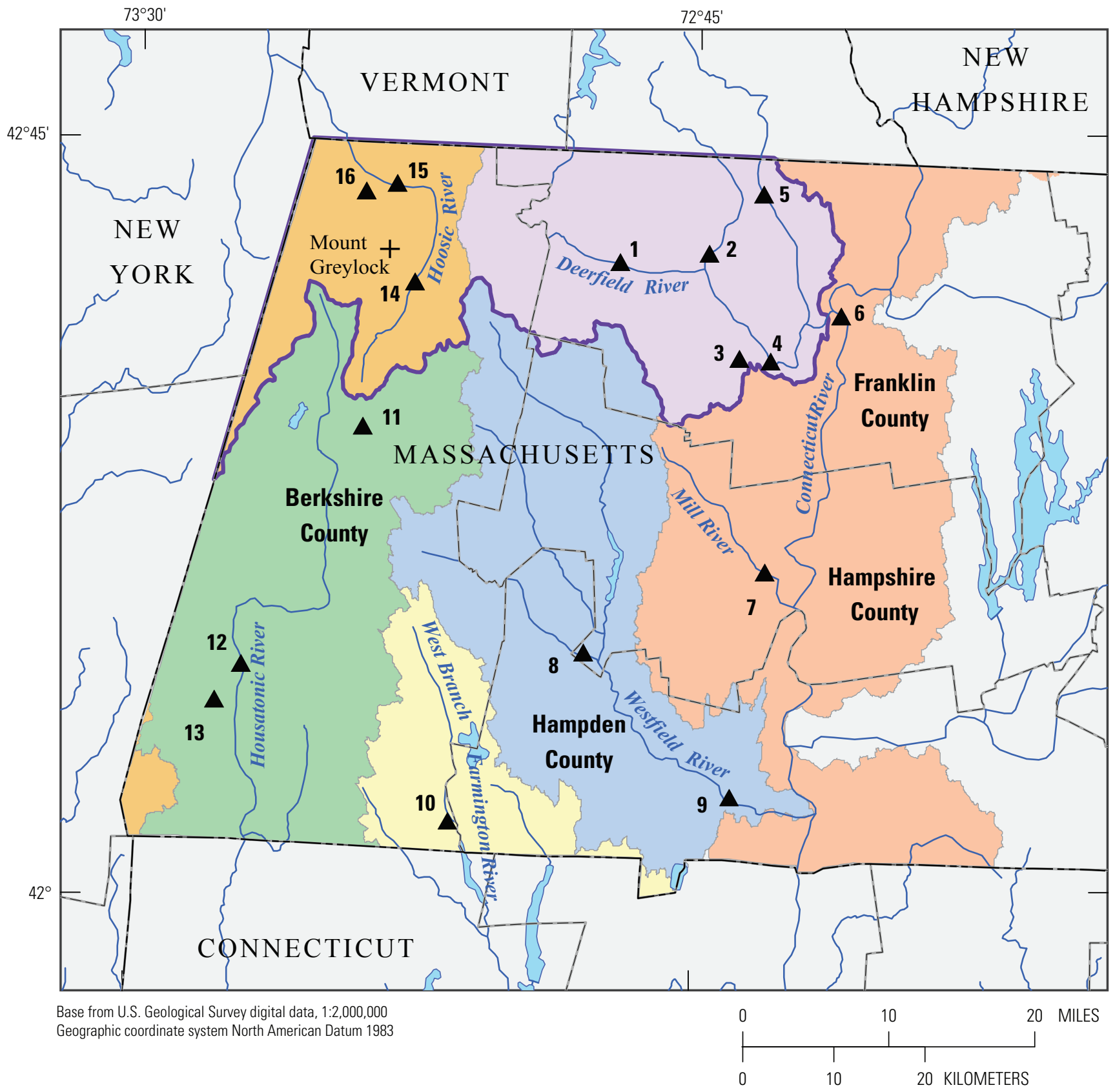

EXPLANATION

Major river basin

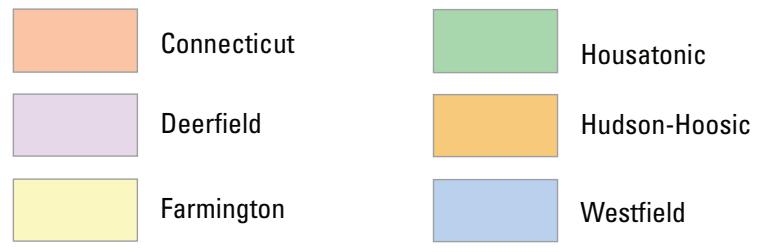

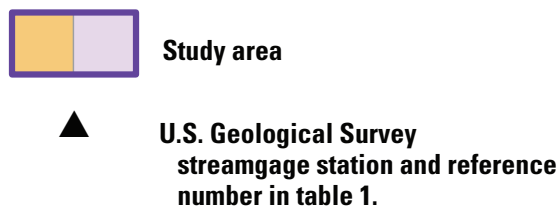

Figure 1. Locations of U.S. Geological Survey streamgages with at least 25 years of record in western Massachusetts. 
Massachusetts is fairly rural with most of the population living in the valleys of the major river basins. The Deerfield River has a drainage area of 665 square miles $\left(\mathrm{mi}^{2}\right)$ in Vermont and Massachusetts (347 $\mathrm{mi}^{2}$ in Massachusetts), has multiple hydroelectric facilities, and is a popular fishing destination for native and stocked trout (Deerfield River Watershed Association, 2005). The Hudson-Hoosic River Basin in Massachusetts covers about $240 \mathrm{mi}^{2}$ and sustains native wild trout (Commonwealth of Massachusetts, 2013). The largest tributary drainage area of the Hudson River in Massachusetts is that of the Hoosic River, which originates in western Massachusetts and flows north and west through Vermont and into New York State.

\section{Tropical Storm Irene}

After leaving a wake of destruction through the Caribbean, eastern North Carolina, and eastern New Jersey, Irene made landfall east of New York City as a tropical storm and then moved northeast over northwestern Connecticut and into western Massachusetts before continuing northeast to Vermont (Fanelli and Fanelli, 2011) (fig. 2). The highest observed rainfall totals from Irene in western Massachusetts were 9.92 inches (in.) in Conway and 9.75 in. in Ashfield (National Weather Service, 2011). The Northeast Regional Climate Center ranked August 2011, with an average rainfall for Massachusetts of 10.05 in., as the second wettest August in 117 years of precipitation records for Massachusetts; the wettest year was 1955 with 13.52 in. of rainfall (Northeast Regional Climate Center, 2011). Precipitation in western Massachusetts during August 2011 was 11.21 in., more than 3 times higher than the average August precipitation (3.41 in.) (Massachusetts Department of Conservation and Recreation, 2011). During August 2011 before the arrival of tropical storm Irene, western Massachusetts already had saturated soils from abundant rainfall, resulting in conditions susceptible to flash flooding (Northeast Regional Climate Center, 2011).

Peak gage heights and streamflows from tropical storm Irene were recorded at 16 long-term ( 25 or more years of record) USGS streamgages in western Massachusetts on August 28 or 29, 2011 (fig. 1 and table 1). Most of the streamgages reached peak gage heights within about 20 hours of the start of the rainfall, similar to USGS 01332500
Hoosic River near Williamstown, Mass. (fig. 3A). Some streamgages reached a peak gage height in about 4 hours; for example, the gage height at USGS 01170000 Deerfield River near West Deerfield, Mass. (reference number 4 on fig. 1), increased from about $5 \mathrm{ft}$ to nearly $24 \mathrm{ft}$ in less than 4 hours (fig. 3B). This rapid response resulted from wet antecedent soil conditions and very intense rainfall. Eight of 16 USGS streamgages in western Massachusetts with long-term records (ranging from 27 to 108 years) set new records for peak streamflows (U.S. Geological Survey, 2013) during tropical storm Irene (table 1).

\section{High-Water Marks}

HWMs are the evidence of the highest water levels during a flood (Benson and Dalrymple, 1967). Bits of material, such as seeds, tree needles, grass, leaves, woody debris, trash, or sediment, that are transported by floodwaters sometimes remain on tree bark, buildings, or fences at the highest water level, leaving a trail to document the height of water (fig. 4). Scour lines in streambanks generally are less accurate and more variable than HWMs from debris or stains. The most useful HWMs tend to result from water that was moving at a low velocity with minimal wave action, usually at some distance from the main river channel or water body. Optimally, HWMs are identified immediately following peak flood levels because over time, rain, wind, and sun can wash, blow, or fade away the HWM material that depict the peak. The general methods used to identify and document HWMs are described by Benson and Dalrymple (1967).

The Deerfield and Hudson-Hoosic River Basins in northwestern Massachusetts, identified by FEMA as having more flood damage from tropical storm Irene than other areas of western Massachusetts, were the focus of this effort to document HWMs. From August 31 through September 30, 2011, the USGS identified and flagged $323 \mathrm{HWMs}$ in those two river basins (fig. 5 and appendix 1). In the Deerfield River Basin, $260 \mathrm{HWMs}$ were flagged at 104 locations on 12 different stream reaches. In the Hudson-Hoosic River Basin, 63 HWMs were flagged at 30 locations on 3 different stream reaches. Of the $323 \mathrm{HWMs}$ that were flagged, 318 were surveyed directly, and 5 were surveyed by an estimated method (described in the section "Surveying"). 


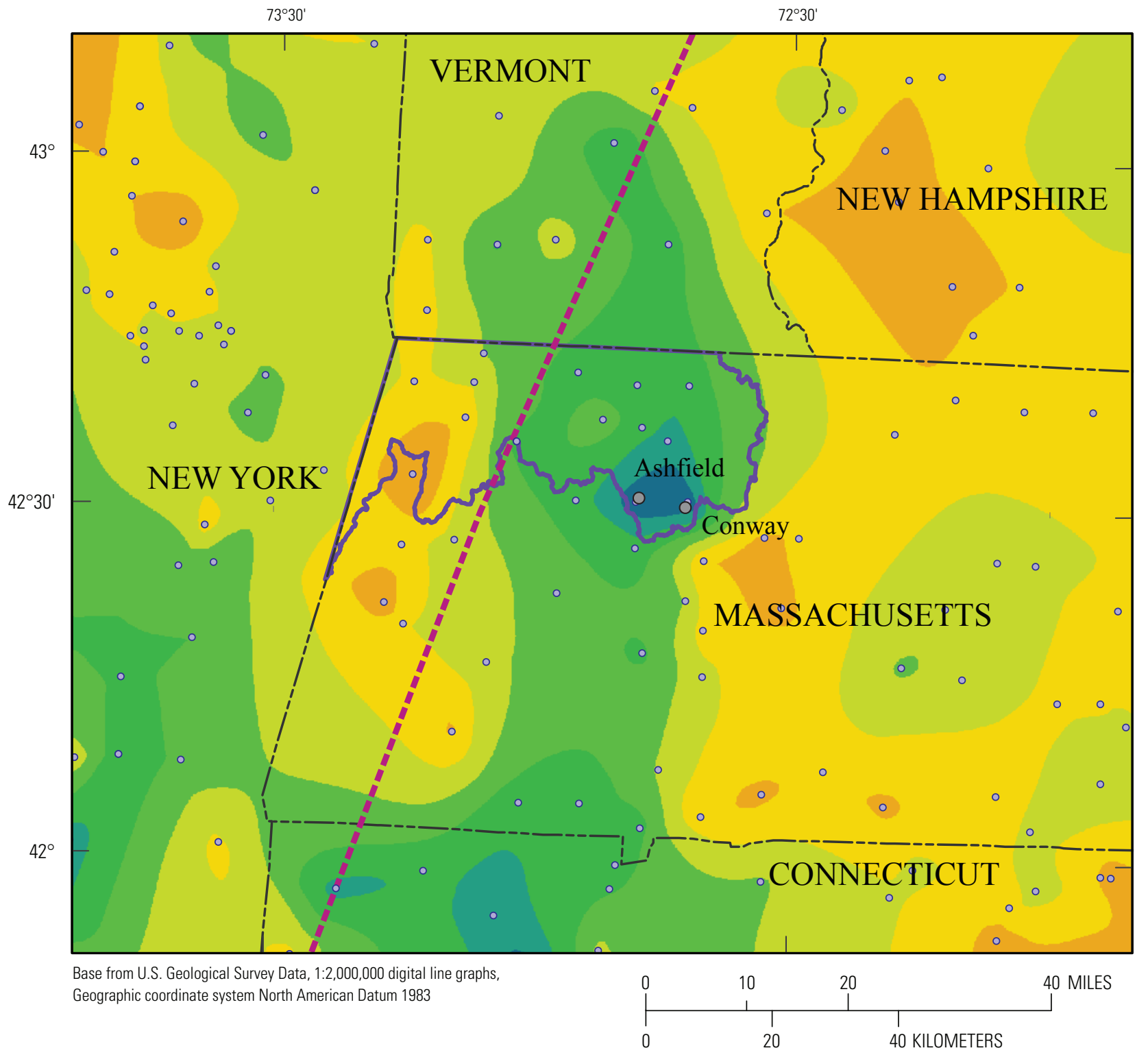

EXPLANATION

Precipitation amounts, in inches

\begin{tabular}{|l}
\hline$>3$ to 4 \\
$>4$ to 5 \\
$>5$ to 6 \\
$>6$ to 7 \\
$>7$ to 8 \\
$>8$ to 9 \\
$>9$ to 11 \\
\hline$>11$ to 13
\end{tabular}

Study Area

- Path of tropical storm Irene

- Precipitation data points

Figure 2. Distribution of rainfall and path of tropical storm Irene across western Massachusetts on August 28-29, 2011. Information on the precipitation data points and the path of tropical storm Irene is from the National Oceanic and Atmospheric Administration (2011a and b). (>, greater than) 
要

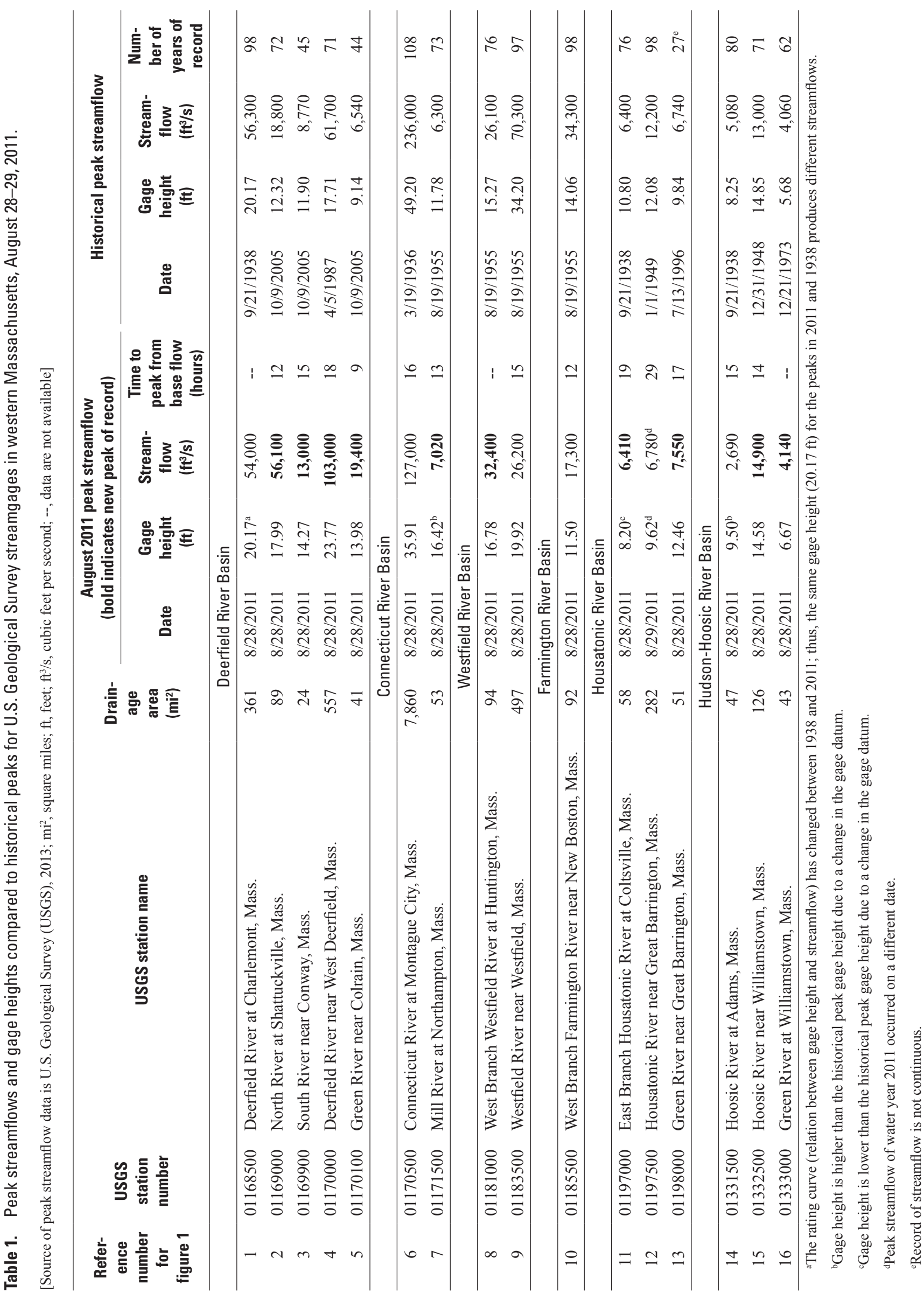


USGS 01332500 HOOSIC RIVER NEAR HILLIAHSTOHN, MA
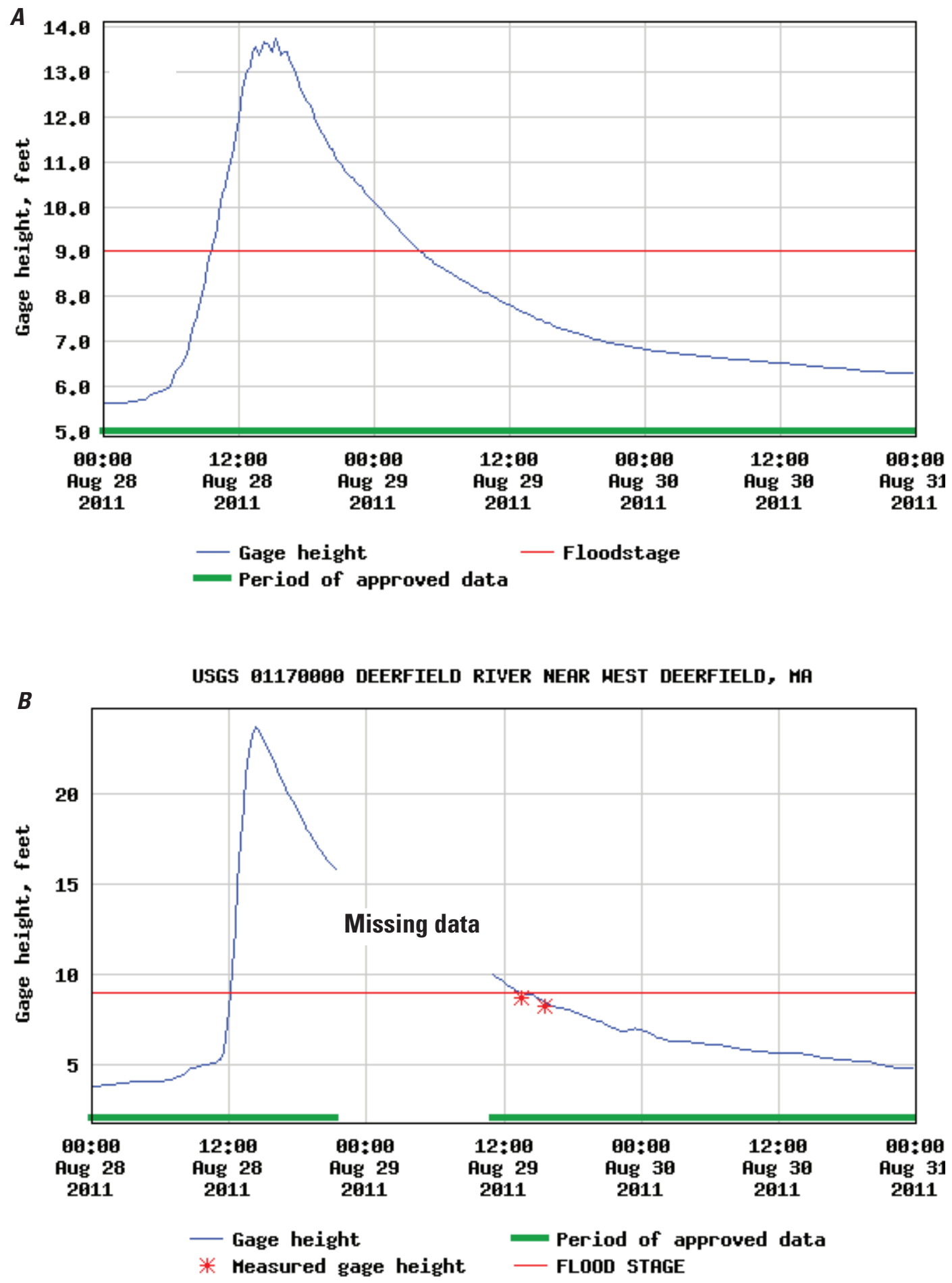

Figure 3. Hydrographs for U.S. Geological Survey streamgages A, Hoosic River near Williamstown (station 01332500) and $B$, Deerfield River near West Deerfield (station 01170000) in Massachusetts, showing a rapid rise in gage height due to tropical storm Irene, August 28-29, 2011. About 14 hours of data are missing in the station 01170000 hydrograph due to equipment malfunction. 


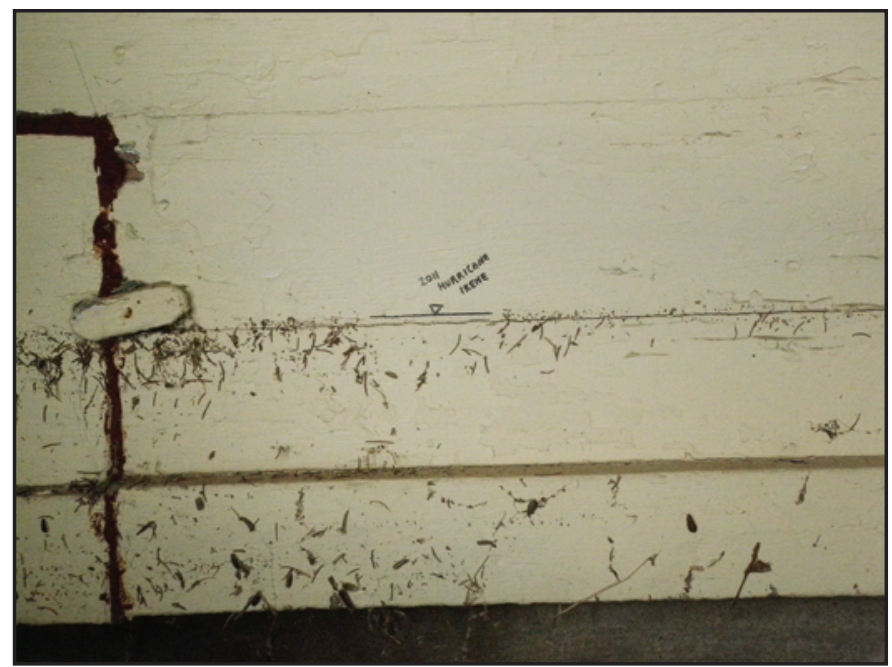

A. HWM-MA-EBNORTH-160

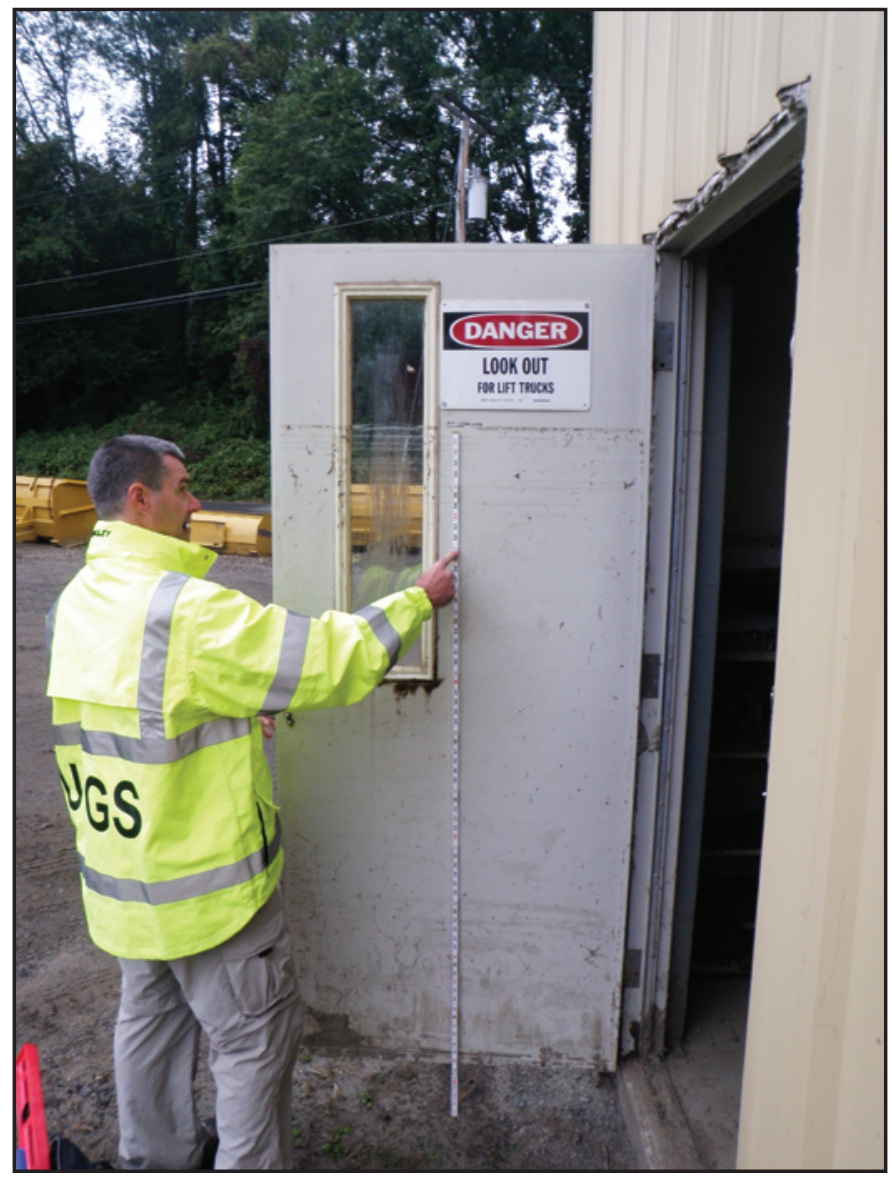

B. HWM-MA-GREEN-079

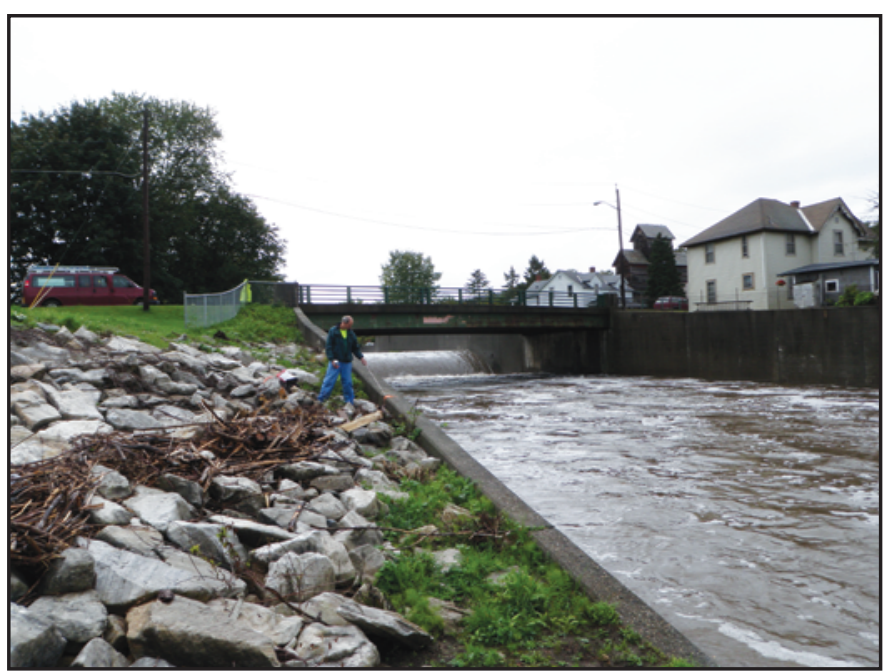

C. HWM-MA-HOOSIC-276

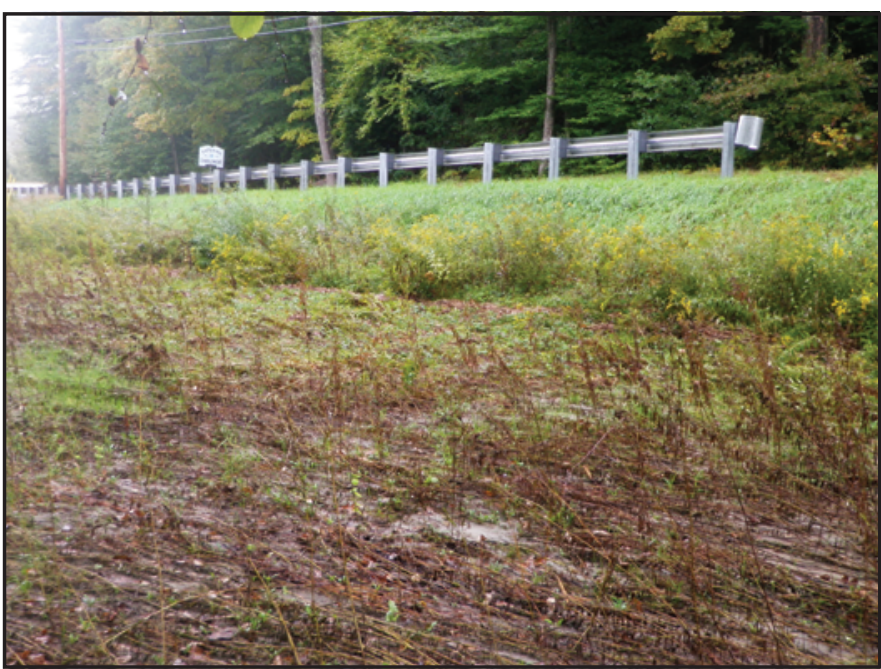

D. HWM-MA-CHICKLEY-225

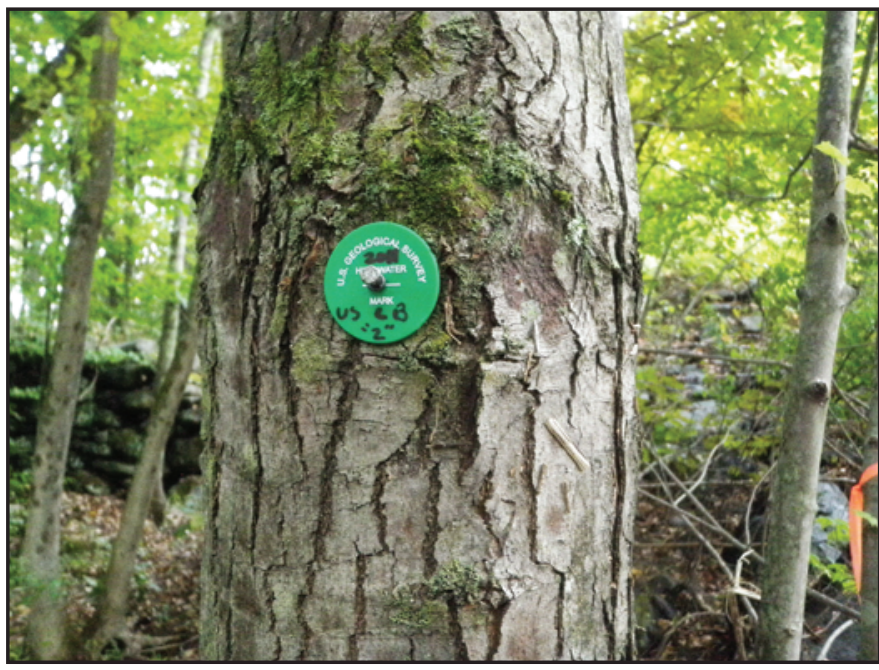

\section{E. HWM-MA-EBNORTH-157}

Figure 4. Examples of high-water marks associated with flooding from tropical storm Irene in the Deerfield and Hudson-Hoosic River Basins in northwestern Massachusetts, August 28-29, 2011: $A, B$, mud and debris line on buildings; $C$, debris on the ground; $D$, wash line on the ground; and $E$, debris on tree. 

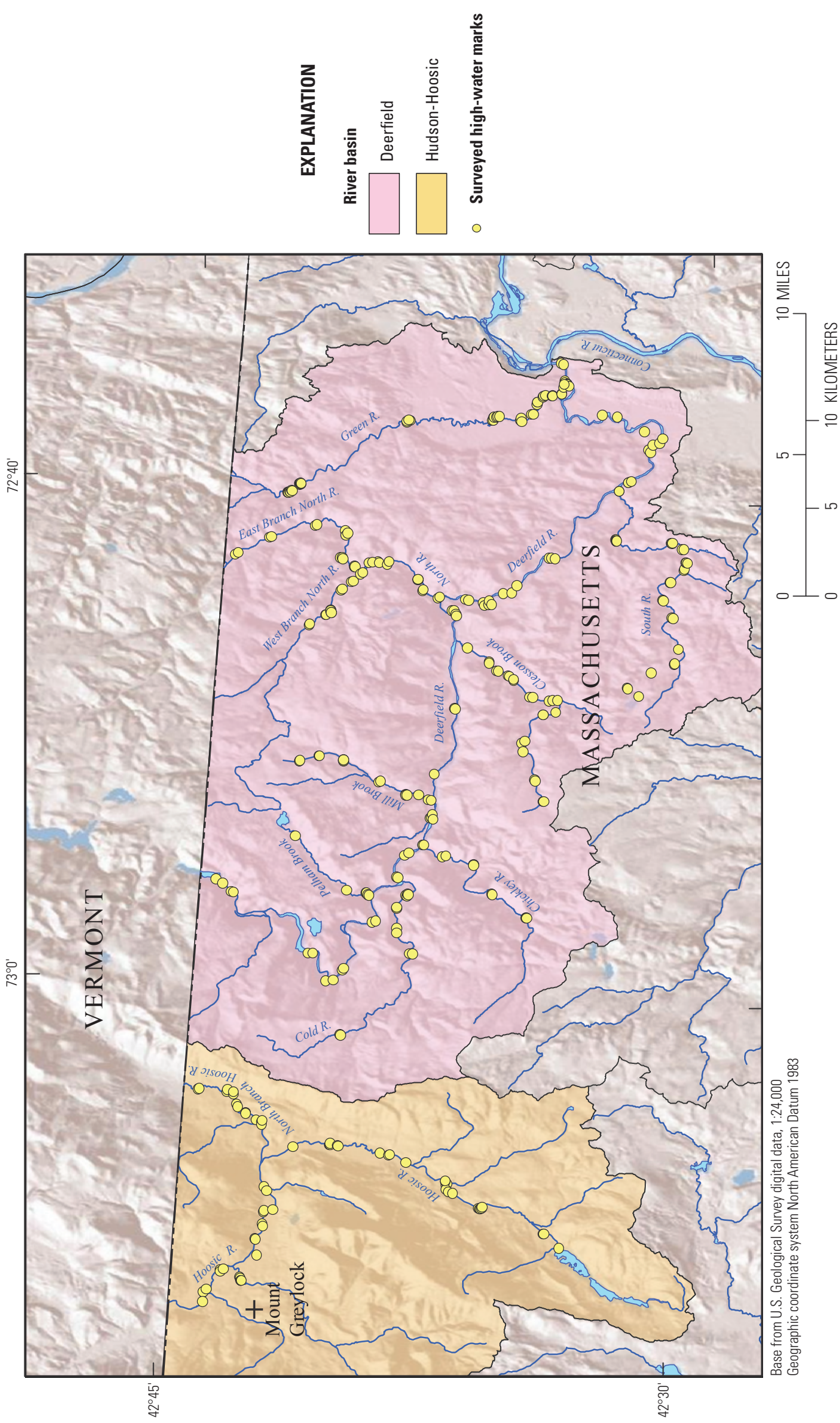

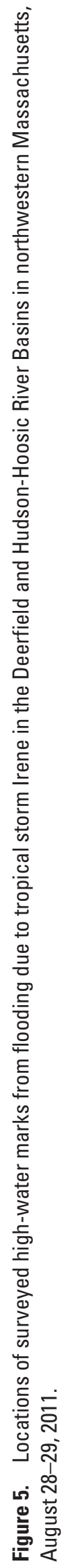




\section{Identification and Flagging}

USGS field personnel working in pairs identified and flagged HWMs at locations upstream and downstream from structures along the largest stream reaches within the Deerfield and Hudson-Hoosic River Basins. Targeted structures included bridges for State, city, or town roads, trains, driveways, or pedestrians; dams; wastewater-treatment and other infrastructure facilities; and USGS streamgages. At each structure, attempts were made to find at least one upstream and one downstream HWM whose quality could be characterized as "good" or "excellent" according to a quantitative accuracy scale (table 2; modified from Lumia and others, 1987). For each HWM, a durable identification mark was made using a USGS HWM disk, stake, chisel mark, or permanent pen (fig. 4). Survey flagging was placed at each HWM location to facilitate the ability of survey crews to find the location at a later date. Information recorded on field forms for each HWM included a physical description of the HWM, horizontal location by latitude and longitude using measurements from a handheld Global Positioning System (GPS), rating of general accuracy (Lumia and others, 1987), description of the durable identification mark left by the USGS crew, and directions for survey crews to find the HWM. Photographs of the HWMs and the surrounding area were taken as part of the documentation $^{1}$ and to help future survey crews find the marks.

\section{Surveying}

Elevations of most of the HWMs that had been identified and flagged during August and September 2011 were surveyed from June through August 2012 to NAVD 88 using the Global Navigation Satellite System, survey grade GPS receivers, and total station surveying equipment. Surveying methods followed those described by Rydlund and Densmore (2012). Eleven of the HWMs flagged during August and September 2011 were surveyed during April and May 2013. Five of the original $323 \mathrm{HWMs}$ could not be found (HWM-MA-CLESSON-202, HWM-MA-DEERFIELD-031, HWM-MA-GREEN-092, HWM-MA-GREEN-093, and HWM-MA-WBNORTH-175 in appendix 1) because either the HWM had been removed or the elevation had clearly changed. The elevations for these five HWMs were estimated by surveying at the ground elevation that was described when the site was flagged in August and September 2011 and adding the distance from the ground to the HWM, as measured by tape and recorded in the field notes. GPS surveys were conducted using Trimble ${ }^{\circledR}$ R8 GPS system receivers. If the HWM itself could not be physically accessed for the survey, other options

\footnotetext{
${ }^{1}$ Photographs of the HWMs are available by contacting the Chief of the Massachusetts-Rhode Island Office of the New England Water Science Center, dc_ma@usgs.gov.
}

Table 2. Quantitative scale to rate accuracy of high-water marks (modified from Lumia and others, 1987).

$[ \pm$, plus or minus; $>$, greater than $]$

\begin{tabular}{lc}
\hline Rating & $\begin{array}{c}\text { Accuracy, } \\
\text { in feet }\end{array}$ \\
\hline Excellent & \pm 0.02 \\
Good & \pm 0.05 \\
Fair & \pm 0.10 \\
Poor & \pm 0.20 \\
Very poor & $> \pm 0.20$ \\
\hline
\end{tabular}

were to (1) survey a point directly above or below the HWM and measure the elevation difference to the HWM with a tape measure or (2) survey a surrogate point nearby and use a total station to measure the elevation difference. The GPS receiver was reinitialized (flipped upside down for several seconds or rotated 180 degrees to lose the GPS signals) several times at each point to obtain multiple independent readings. If the vertical elevations of the multiple readings differed by more than about $0.10 \mathrm{ft}$, additional readings were taken until the differences were less than $0.10 \mathrm{ft}$. In most cases, agreement within $0.05 \mathrm{ft}$ was reached.

Continuous real-time differential corrections to the GPS horizontal and vertical positions were made using a proprietary fixed-base station GPS network of receivers operated by KeyNetGPS, Inc. (2013). The fixed-base station GPS network of receivers and associated software determined corrections for satellite signals received by the field GPS receiver for ionosphere and other atmospheric disturbances. The fixed-base station GPS network of receivers continuously streamed data to a central server that calculated corrections in real time to the field GPS receiver. The five fixed-base station GPS receivers closest to the western Massachusetts survey area (HAMP in western Massachusetts, NYAB and NYHS in eastern New York, and VTBE and VTD2 in southern Vermont) composed the network that was utilized for these corrections (KeyNetGPS, Inc., 2013).

Checks on the accuracy of the GPS measurements were made by comparing instrument readings from two types of survey equipment at 10 National Geodetic Survey (NGS) benchmarks with vertical datums throughout the study area between June and August 2012 (table 3). Differences in elevations between NGS benchmarks and those determined using survey equipment at the benchmarks yielded a vertical root mean square error of $0.15 \mathrm{ft}$. 
Table 3. Quality assurance of survey equipment used by the U.S. Geological Survey to determine positions of high-water marks from tropical storm Irene relative to National Geodetic Survey benchmarks in and near the Deerfield and Hudson-Hoosic River Basins, western Massachusetts, June through August 2012.

[NAD 83, North American Datum of 1983; NAVD 88, North American Vertical Datum of 1988; NGS, National Geodetic Survey; ft, feet; WGS 84, World Geodetic System of 1984]

\begin{tabular}{|c|c|c|c|c|c|c|c|c|}
\hline \multirow{3}{*}{ Date } & \multicolumn{2}{|c|}{ Benchmark } & \multirow{3}{*}{ County } & \multicolumn{3}{|c|}{$\begin{array}{l}\text { Surveyed, } \\
\text { in NAD 83' }\end{array}$} & \multirow{3}{*}{$\begin{array}{l}\text { NGS reference, } \\
\text { NAVD } 88 \\
\text { elevation, } \\
\text { adjusted } \\
\text { (ft) }\end{array}$} & \multirow{3}{*}{$\begin{array}{c}\text { Elevation } \\
\text { difference } \\
\text { between NGS } \\
\text { and surveyed } \\
\text { values } \\
\text { (ft) }\end{array}$} \\
\hline & \multirow{2}{*}{$\begin{array}{c}\text { Designation } \\
\text { (stamped } \\
\text { name) }\end{array}$} & \multirow{2}{*}{$\begin{array}{l}\text { Permanent } \\
\text { identifier }\end{array}$} & & $\begin{array}{c}\text { Latitude } \\
\text { (north) }\end{array}$ & $\begin{array}{c}\text { Longitude } \\
\text { (west) }\end{array}$ & \multirow{2}{*}{$\begin{array}{c}\text { NAVD } 88 \\
\text { elevation } \\
\text { (ft) }\end{array}$} & & \\
\hline & & & & $\begin{array}{l}\text { Decimal } \\
\text { degrees }\end{array}$ & $\begin{array}{l}\text { Decimal } \\
\text { degrees }\end{array}$ & & & \\
\hline \multicolumn{9}{|c|}{ Trimble TSC2® Survey Unit } \\
\hline $6 / 5 / 2012$ & P9 & MZ0415 & BERKSHIRE & 42.632368 & 73.113672 & 759.88 & 760.02 & 0.14 \\
\hline $6 / 7 / 2012$ & L9 & MZ0409 & BERKSHIRE & 42.553868 & 73.165154 & 974.58 & 974.67 & 0.09 \\
\hline $6 / 12 / 2012$ & E11 & MZ0280 & FRANKLIN & 42.616148 & 72.743125 & 506.44 & 506.36 & -0.08 \\
\hline $6 / 14 / 2012$ & $\mathrm{X} 40$ & MZ1181 & FRANKLIN & 42.580416 & 72.599227 & 144.21 & 144.19 & -0.02 \\
\hline $6 / 19 / 2012$ & S5 & MZ0232 & FRANKLIN & 42.568834 & 72.591037 & 188.66 & 188.66 & 0.00 \\
\hline $6 / 21 / 2012$ & $\mathrm{X} 40$ & MZ1181 & FRANKLIN & 42.580416 & 72.599227 & 144.10 & 144.19 & 0.09 \\
\hline $8 / 2 / 2012$ & $\mathrm{X} 40$ & MZ1181 & FRANKLIN & 42.580416 & 72.599227 & 144.39 & 144.19 & -0.20 \\
\hline $8 / 10 / 2012$ & S5 & MZ0232 & FRANKLIN & 42.568834 & 72.591037 & 188.68 & 188.66 & -0.02 \\
\hline $8 / 21 / 2012$ & S5 & MZ0232 & FRANKLIN & 42.568834 & 72.591037 & 188.59 & 188.66 & 0.07 \\
\hline $8 / 23 / 2012$ & D33 NEPA & MZ0286 & FRANKLIN & 42.560074 & 72.678673 & 240.19 & 240.29 & 0.10 \\
\hline \multicolumn{9}{|c|}{ Trimble TSC3® Survey Unit } \\
\hline $6 / 6 / 2012$ & N11 & MZ0369 & BERKSHIRE & 42.738259 & 73.210933 & 593.49 & 593.57 & 0.08 \\
\hline $6 / 13 / 2012$ & $\mathrm{X} 40$ & MZ1181 & FRANKLIN & 42.580416 & 72.599227 & 144.17 & 144.19 & 0.02 \\
\hline $6 / 15 / 2012$ & Y9 & MZ0287 & FRANKLIN & 42.561383 & 72.679986 & 240.34 & 240.42 & 0.08 \\
\hline $6 / 21 / 2012$ & D33 NEPA & MZ0286 & FRANKLIN & 42.560075 & 72.678673 & 240.49 & 240.29 & -0.20 \\
\hline 6/26/2012 & $\mathrm{X} 40$ & MZ1181 & FRANKLIN & 42.580416 & 72.599227 & 144.14 & 144.19 & 0.05 \\
\hline $7 / 12 / 2012$ & $\mathrm{~J} 33$ & MZ0266 & FRANKLIN & 42.642113 & 72.923880 & 601.82 & 602.19 & 0.37 \\
\hline $7 / 12 / 2012$ & F11 & MZ0265 & FRANKLIN & 42.642158 & 72.924815 & 603.21 & 603.30 & 0.09 \\
\hline 7/17/2012 & E11 & MZ0280 & FRANKLIN & 42.616147 & 72.743124 & 506.62 & 506.36 & -0.26 \\
\hline 7/19/2012 & E11 & MZ0280 & FRANKLIN & 42.616148 & 72.743125 & 506.65 & 506.36 & -0.29 \\
\hline $8 / 15 / 2012$ & $\mathrm{X} 40$ & MZ1181 & FRANKLIN & 42.580416 & 72.599227 & 144.01 & 144.19 & 0.18 \\
\hline $8 / 21 / 2012$ & S5 & MZ0232 & FRANKLIN & 42.568834 & 72.591037 & 188.72 & 188.66 & -0.06 \\
\hline
\end{tabular}

${ }^{1}$ Units of the original horizontal survey were in WGS 84; transformation to NAD 83 results in negligible differences. 


\section{Uses of Data}

HWM elevations are used in hydrologic studies in several ways: to confirm peak river stages, to help compute peak streamflows, to calibrate hydraulic models, and to update flood inundation and flood insurance rate maps. In western Massachusetts, HWMs from tropical storm Irene have been used to determine or confirm instantaneous peak river gage heights at 10 USGS streamgages, 2 of which were up to 20 miles outside the study area. For example, at USGS streamgage Deerfield River at Charlemont (01168500), flood streamflows overtopped the instrument shelter, and HWMs were used to determine the peak river gage height that would otherwise have been lost. At USGS streamgages North River at Shattuckville (01169000), South River near Conway (01169900), Green River near Colrain (01170100), West Branch Westfield River at Huntington (01181000, outside the study area), and Green River at Williamstown (01333000), the HWMs were used to adjust the streamgages recorded peak gage heights to higher values; this was needed to fix values that were incorrectly recorded too low as a result of drawdown or intakes with slow response times. At USGS streamgages Deerfield River near West Deerfield (01170000), Mill River at Northampton (01171500, outside the study area), Hoosic River at Adams (01331500), and Hoosic River near Williamstown (01332500), HWMs were used to confirm peak river stages that were either recorded electronically or observed from a crest-stage gage.

\section{Summary}

On August 28-29, 2011, intense rainfall from tropical storm Irene of 3 to 10 inches caused widespread flooding in western Massachusetts. August precipitation in western Massachusetts prior to tropical storm Irene had already saturated the ground resulting in conditions prone to flooding. Eight of 16 long-term U.S. Geological Survey (USGS) streamgages in western Massachusetts that had been in operation for more than 25 years recorded new streamflow peaks from tropical storm Irene. In order to document the peak river stage elevations from tropical storm Irene in western Massachusetts, the Federal Emergency Management Agency authorized a Mission Assignment for the USGS to identify and flag high-water marks (HWMs) along affected river reaches in the Deerfield and Hudson-Hoosic River Basins and to survey their elevations.
From August 31 through September 30, 2011, the U.S. Geological Survey identified and flagged 323 HWMs: 260 in the Deerfield River Basin at 104 locations on 12 different stream reaches and 63 in the Hudson-Hoosic River Basin at 30 locations on 3 different stream reaches. The HWMs were typically identified upstream and downstream from structures (bridges, dams, and wastewater-treatment facilities, or USGS streamgages) on the selected river reaches. At each flagged HWM, information including the physical description of the HWM, horizontal location (latitude and longitude), rating of accuracy, description of the durable marker left by the USGS crew, and directions for finding the HWM at a later date by survey crews, was recorded on field forms. In addition, photographs of the HWM and surrounding area were taken.

Elevations of HWMs were surveyed from June through August 2012, and April and May 2013 vertically to the North American Vertical Datum of 1988 (NAVD 88) and horizontally to the North American Datum of 1983 (NAD 83) using the Global Navigation Satellite System, survey grade Global Positioning System (GPS) receivers, and total station surveying equipment. Continuous real-time differential corrections to the GPS positions were made using a proprietary fixedbase station GPS network of receivers. Quality-assurance GPS measurements made at 10 established National Geodetic Survey benchmarks with a vertical datum throughout the study area yielded a vertical root mean square error of 0.15 feet. Five of the original $323 \mathrm{HWM}$ elevations that could not be found were surveyed at estimated points.

\section{Acknowledgments}

The authors thank the following U.S. Geological Survey (USGS) field personnel for identifying and flagging highwater marks during September 2011: Christopher Bruet, Paul Friesz, Pam Lombard, Steven O'Brien, John O'Byran, Gene Parker, David Thompson, and Andrew Waite. The authors thank the following USGS field personnel for surveying highwater marks from June through August 2012, and April and May 2013: Roy Apostle, David Armstrong, Dennis Claffey, Adam Hudziec, Andrew Massey, and William Podolski. The authors also thank the many landowners who allowed access to their property to identity, flag, and survey high-water marks. 


\section{References Cited}

Benson, M.A., and Dalrymple, Tate, 1967, General field and office procedures for indirect discharge measurements: U.S. Geological Survey Techniques of Water-Resources Investigations, book 3, chap. A1, $30 \mathrm{p}$.

Commonwealth of Massachusetts, 2013, Hudson River Watershed, accessed April 12, 2013, at http://www.mass. gov/eea/air-water-climate-change/preserving-waterresources/mass-watersheds/hudson-river-watershed.html.

Deerfield River Watershed Association, 2005, Deerfield by the numbers: watershed facts and figures, accessed April 12, 2013, at http://www.deerfieldriver.org/facts.html.

Fanelli, C., and Fanelli, P., 2011, NOAA water level and meteorological data report-Hurricane Irene: U.S. Department of Commerce, National Oceanic and Atmospheric Administration, National Ocean Service Center for Operational Oceanographic Products and Services. (Also available at http://tidesandcurrents.noaa.gov/publications/Hurricane Irene_Water_Level_and_Meteorological_Data_Report.pdf.)

Federal Emergency Management Agency, 2013, Massachusetts Tropical Storm Irene (DR-4028), accessed February 12, 2013, at http://www.fema.gov/disaster/4028.

KeyNetGPS, Inc., 2013, A Trimble VRS Network, accessed February 13, 2013, at http://www.keynetgps.com/.

Lumia, Richard, Burke, P.M., and Johnston, W.H., 1987, Flooding of December 29, 1984, through January 2, 1985, in northern New York State, with flood profiles of the Black and Salmon Rivers: U.S. Geological Survey WaterResources Investigations Report 86-4191, 53 p.
Massachusetts Department of Conservation and Recreation, 2011, Monthly precipitation composite, accessed February 12, 2013, at http://www.mass.gov/dcr/watersupply/rainfall/.

National Oceanic and Atmospheric Administration, 2011a, NWS Taunton, Massachusetts - significant weather event, accessed March 11, 2013, at http://www.erh.noaa.gov/box/ displayEvent.php?event=Aug_27-28_2011\&element=pcpn.

National Oceanic and Atmospheric Administration, 2011b, Hurricane Irene, accessed March 11, 2013, at http://www. noaawatch.gov/2011/irene.php.

National Weather Service, 2011, Public Information Statement, Spotter Reports, Taunton, Massachusetts, August 30, 2011, accessed February 12, 2013, at http://www.erh.noaa.gov/box/displayEvent. php?event=Aug_27-28_2011\&element=pcpn).

Northeast Regional Climate Center, 2011, New England Climate, August 2011, v. 111, no. 8, accessed February 12, 2013, at http://www.nrcc.cornell.edu/page_summaries.html.

Rydlund, P.H., Jr., and Densmore, B.K., 2012, Methods of practice and guidelines for using survey-grade global navigation satellite systems (GNSS) to establish vertical datum in the United States Geological Survey: U.S. Geological Survey Techniques and Methods, book 11, chap. D1, 102 p. with appendixes.

U.S. Geological Survey, 2013, Peak streamflow for the Nation, accessed May 31, 2013, at http://nwis.waterdata.usgs.gov/ nwis/peak? 
Appendix 1. Elevations of High-Water Marks Surveyed in the Deerfield and Hudson-Hoosic River Basins in Northwestern Massachusetts Resulting from Flooding from Tropical Storm Irene, August 28-29, 2011

[Available separately at http://pubs.usgs.gov/ds/775/]

Appendix 2. GoogleEarth Map of High-Water Marks in the Deerfield and Hudson-Hoosic River Basins in Northwestern Massachusetts Resulting from Flooding from Tropical Storm Irene, August 28-29, 2011

[Available separately at http://pubs.usgs.gov/ds/775/] 
Prepared by the Pembroke and West Trenton Publishing Service Centers.

For more information concerning this report, contact:

Office Chief

U.S. Geological Survey

New England Water Science Center

Massachusetts-Rhode Island Office

10 Bearfoot Road

Northborough, MA 01532

dc_ma@usgs.gov

or visit our Web site at:

http://ma.water.usgs.gov 


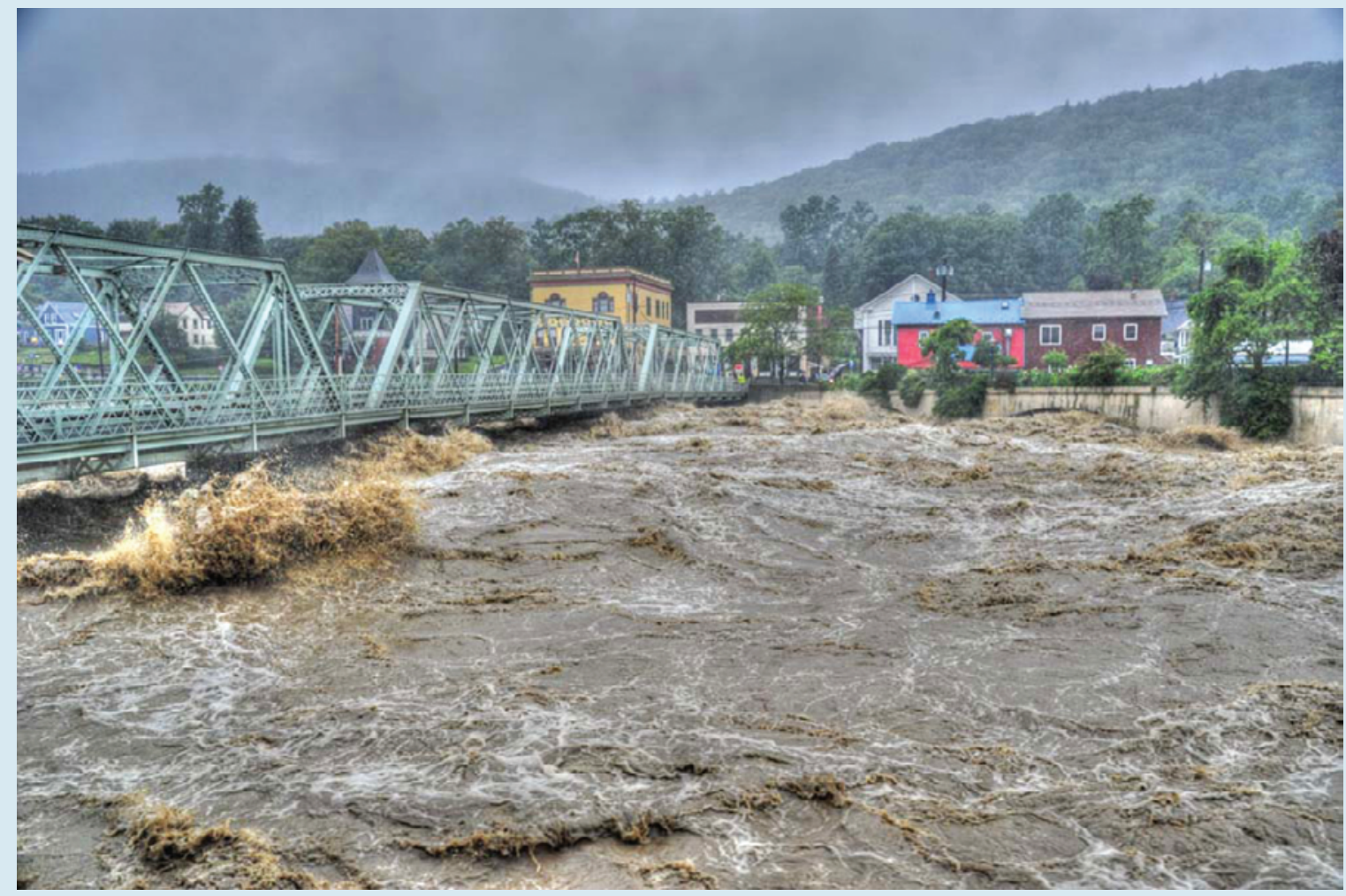

